\title{
The Szathmary Culinary Archives
}

\section{O U I S S Z A T H M A R Y}

I can't recall a time when I did not have books around me. My family in Hungary was rich in books, not money. We had a standing account with one book dealer that had been active since the 1790s. It isn't strange, then, that I grew up to become a book collector, although I never expected to own some 45,000 of them.

Of these, only 18,000 are cookbooks. I remember the first book I bought within a year after coming to this country in 1951 with a small handbag and $\$ 1.10$ in my pocket. It was at a Times Square bookshop in New York that I purchased, for 19 cents, a little volume by Ludwig Bemelmans. I never stopped buying books since.

Today, my culinary collection includes more than cookbooks. There are pamphlets and menus, some dating back to the beginning of menu writing; some are autographed with names such as Winston Churchill, Enrico Caruso, Juan and Evita Peron, along with the signatures of kings and queens, presidents, politicians, actors, musicians, and Nobel prize winners. Everything in the collection, including artifacts and original art, has some link with gastronomy.

Some of these items are collections within collections: colonial and early American cookbooks, manuscripts on cookery other than recipes, regional cookbooks, first editions of early "trancher" books in several languages. Let me tell you about some of these culinary treats.

Among the manuscripts are letters from just about every president or first lady in American history, including thank you notes for gifts of food, ranging from apples to quail. There is a handwritten shopping list by John Hancock. There's a long letter from Walt Whitman to a friend itemizing, in rather unpoetic language, what he had eaten in two recent meals ("I had some of the chicken for my supper \& found it very nice...."). Ernest Hemingway writes a note to a condiment company in New York requesting a recipe booklet. Thomas Edison writes letters about his dietary peculiarities. And there's an amusing note from a neighbor to Ben Franklin asking for Betsy Franklin's help in getting rid of some maggots in salt pork. 


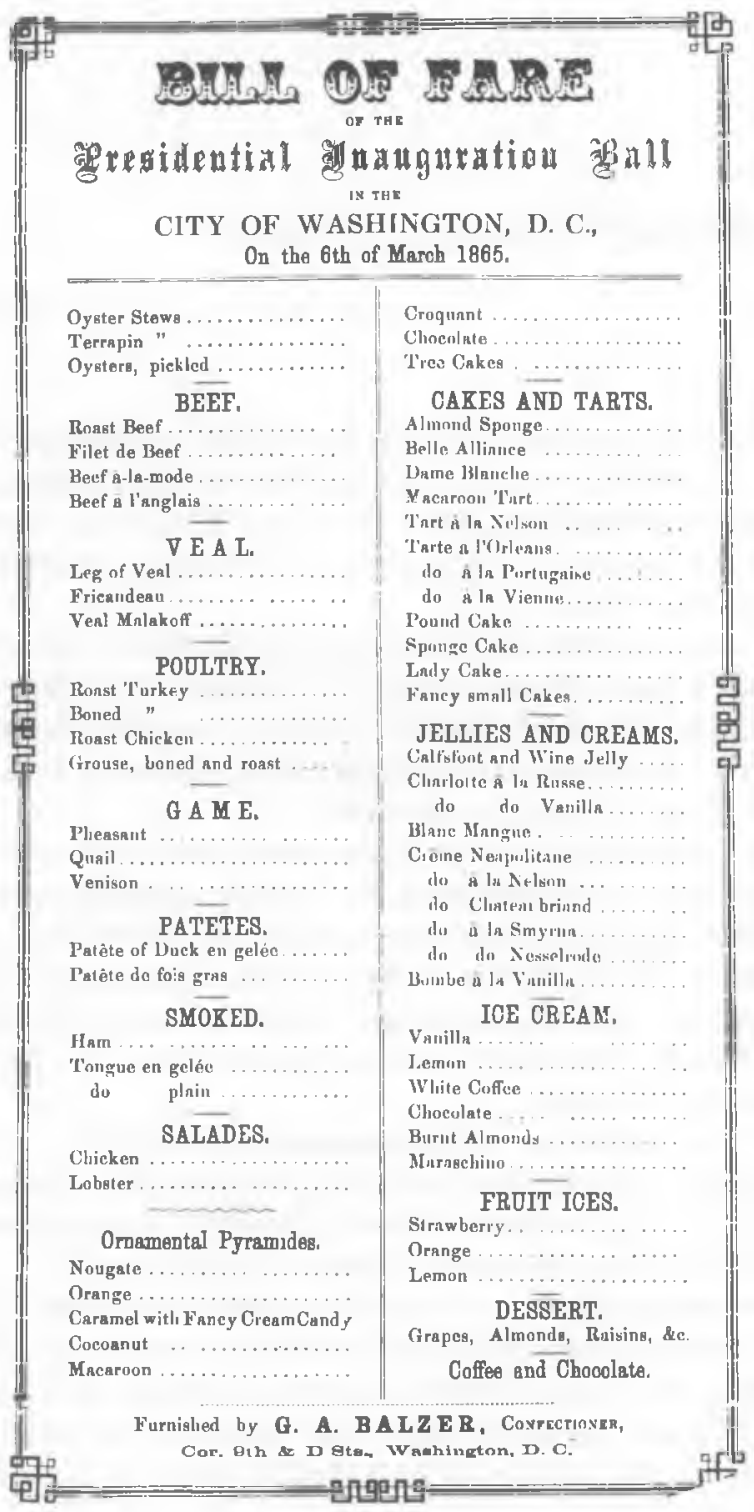

Shown above, in reduced size, is a copy of the bill of fare for the inauguration ball at President Abraham Lincoln's second inauguration in March 1865. From the Szathmary Culinary Archives. 
At least a hundred of the autographed menus are historically interesting. The most significant one, I feel, is the "Bill Of Fare of the Presidential Inauguration Ball in the City of Washington, D. C., On the 6th of March 1865." The president being inaugurated was Abraham Lincoln. I've been told only three copies of this menu are known to exist. My copy is believed to have been brought home after the dinner by Lincoln himself and had been in the family of Lincoln descendants until I purchased it a few years ago.

Other signatures appearing on various menus are those of Charles Dickens, the African explorer Sir Henry Stanley ("Dr. Livingstone, I presume"), Mark Twain, Charles Lindbergh, Nellie Melba, Ichior Hatoyama, Victor Emmanuel III, and Robert Peary, to name a few.

The "trancher" books I mentioned earlier deal with table-side carving. It took me 20 years before I could own the first edition of the very first book to be printed on this subject, along with the first issues in Italian, Spanish, and German. This gives me a complete collection of the first editions of the first trancher books.

My interest in books about food canning arose from my work as a research chef and subsequently as manager of product development for Armour and Company. Through the years, I've been able to collect many of the first and second editions of Nicolas Appert's Le Livre de Tous les Menages, ou l'Art de Conserver in several languages.

The pamphlet collection consists mainly of cookbooks distributed by American food companies during the past century. I own a very rare copy of the first pamphlet published by Gail Borden, founder of the Borden company. My collection of Bordeniana includes several hundred promotional cookbooks, recipe sheets, trade cards, as well as the very latest publications.

Also worth noting are the charity cookbooks, the oldest of which is $A$ Poetical Cook-Book by M.J.M. (Maria J. Moss), published in Philadelphia in 1864. When the author issued the book as a benefit for a hospital for Civil War soldiers, she could not possibly have imagined how popular and effective such publications would become as a means to raise funds for charitable purposes. A century later, in 1964, at least 600 charitable and community cookbooks were published across the country. I'm sure there are many others printed, photocopied, or mimeographed that have never been listed or registered. My own collection consists of more than 500 charitable cookbooks, including several not listed in any bibliography.

There's a great interest in such charitable and regional publications. In 1981 , selections from my collection were put on exhibit in the Chicago Public Library. A surprising attendance at the exhibit of more than 19,000 caused the library to extend the exhibit from one month to three months. 


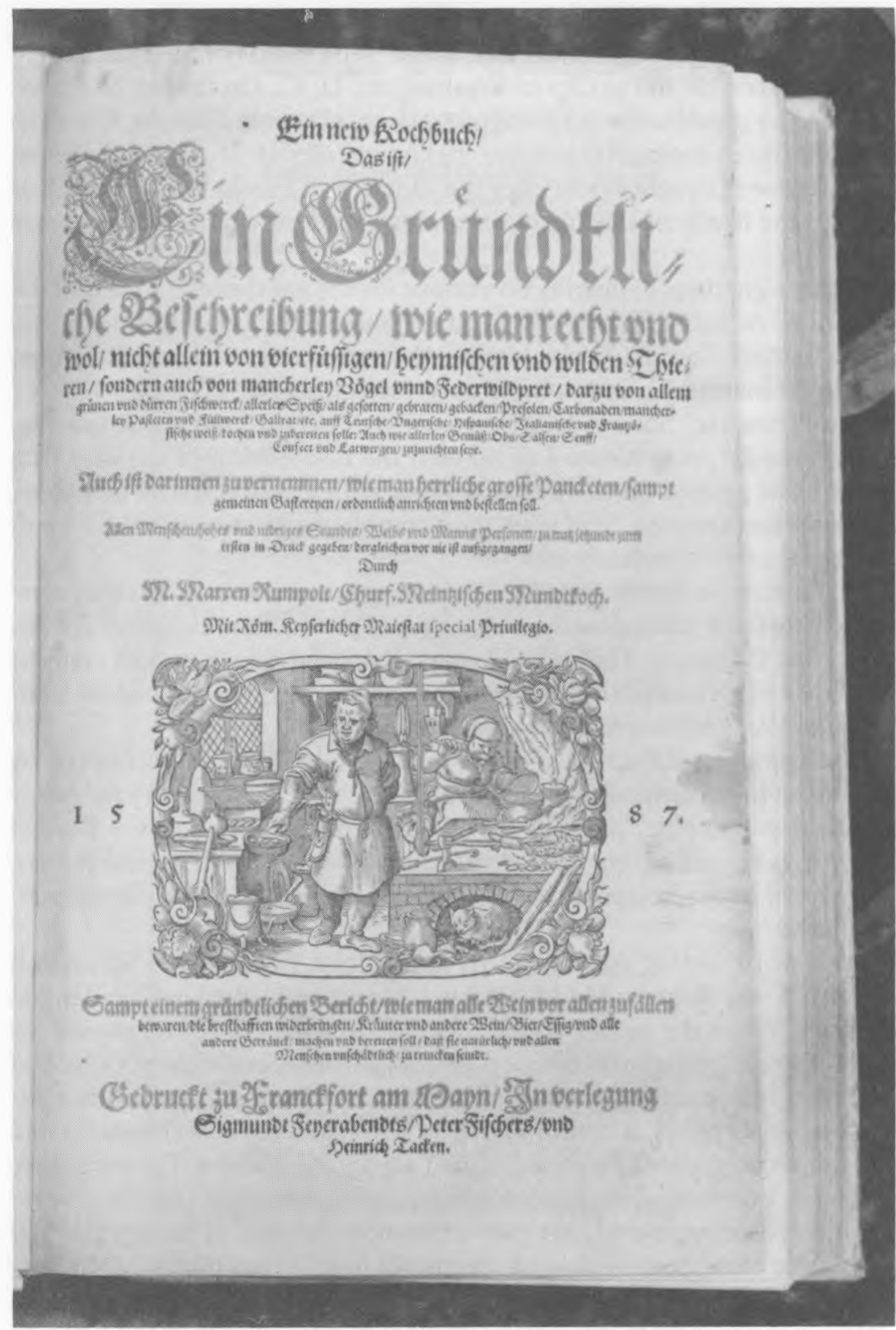

Title page of Marx Rumpolt, Ein new Kochbuch (Frankfurt 1587), the most important cookbook printed to its time of publication in any language in any country. The author explains in the preface that he is a Hungarian who escaped the Turks occupying his homeland. From a copy in the Szathmary Culinary Archives, The University of lowa Libraries. 
Among the artworks in the Szathmary collection are prints, etchings, lithographs, photos, and other graphics pertaining to gastronomy. I have, for example, food-related works of Winslow Homer, Frederic Remington, Rufus Zogbaum, Honore Daumier, Ludwig Bemelmans, and others.

This is not an idle collection. It is in constant use. Two professional librarians work on it. We have a cataloging system modeled after that of the Library of Congress and have modified it so that anything can easily be found not only by catalog number but by the object's location.

Twenty thousand items are listed by title and author. The pamphlets are cross-indexed five ways, because at least half of them have neither title nor author's name showing. To overcome this, we had to catalog them by subject, by company, and by location. If an important illustrator was involved (such as Maxfield Parrish in some early Jello recipe booklets), we added another file card based on the illustrator.

To house this large and varied collection requires 31 rooms in the residential area above my restaurant (The Bakery) in Chicago. The very rare books are kept in a special humidity-controlled room for maximum preservation. An example of something requiring such tender loving care is a leather-covered document, handwritten on vellum in Hungary circa 1490. Incidentally, my collection contains just about every cookbook ever printed in Hungary.

One of the most sought-after and most rare of classic cookbooks was written by a Hungarian. It is Marx Rumpolt's Ein new Kochbuch, in the preface of which the author explains how he escaped the Turks occupying his homeland. The book was published in Frankfurt, in what today is West Germany. In 1987, the book will mark its four hundredth birthday, and authorities say this volume surpassed anything that had been printed from the time of Gutenberg up to its own publication. This 398-year-old "new" cookbook was among the first donated to The University of Iowa. In the collection are cookbooks not only printed in Hungary, but Hungarian cookbooks from all over the world.

The collection never rests. I refer to it constantly for my writing, sometimes even for my cooking and almost always for answering questions on my broadcast programs. I never know what questions a caller will ask, but I feel confident that my library will enable me to answer just about all of them. Of course, many other people are able to use the collection for various research projects.

I appreciate the physical appearance of books almost as much as their contents. There's something heartwarming about the craftsmanship of fine binding, good paper, elegant design, and meticulous printing. I love to hunt for books and browse through little shops. I have standing accounts with book dealers all over the world, including such places as Eng- 


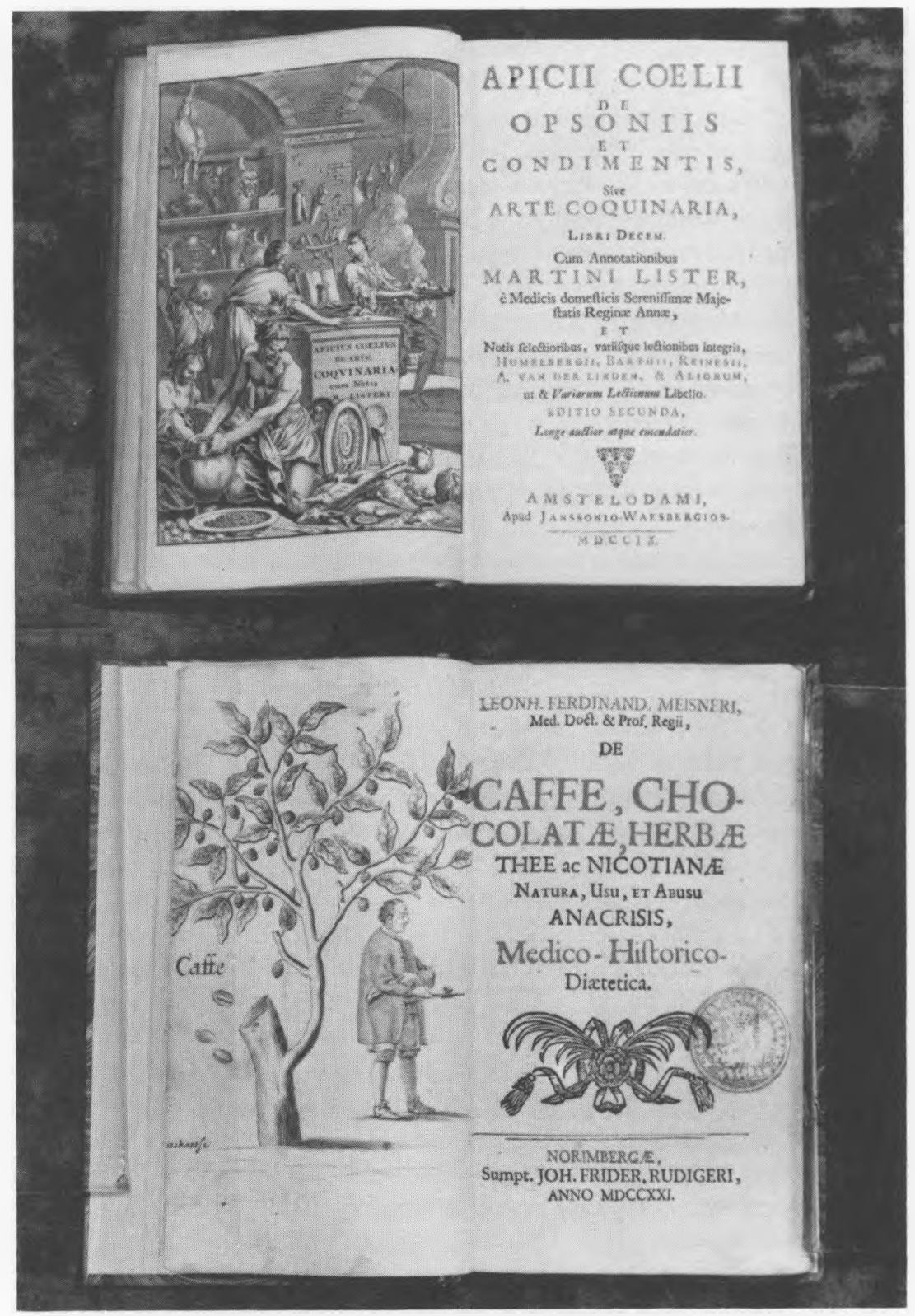

Two eighteenth-century books from the Szathmary collection: Apicius, De oposoniis et condimentis, sive arte coquinaria (Amsterdam 1709), the second book on cookery ever published (an edition of 1541 is also in the collection), and Leonhard Ferdinand Meisner, De caffe, chocolate, herbae, thee ac nicotinae, natura usu et abusu anacrisis ... (Nuremberg 1721). 
land, France, South Africa, and Australia. One never knows where the culinary find of the century will show up.

Anyone who collects knows the pleasure of finding a rare item or a particularly beautiful edition and of sharing that joy with others. That is why I ask that you consider exploring your attic or basement. You may just find that regional lowa cookbook that's been in the family for years, that The University of lowa would be delighted to add to its library. I enjoy my collection. I hope you and others will, too. 